Fnl of Ecclesiastical History, Vol. 53, No. 4, October 2002. (C) 2002 Cambridge University Press 665 DOI : I0.I I 7 /So02204690200427X Printed in the United Kingdom

\title{
The Montmorencys and the Abbey of Sainte Trinité, Caen: Politics, Profit and Reform
}

\author{
by JOAN DAVIES
}

\begin{abstract}
Female religious, especially holders of benefices, made significant contributions to aristocratic family strategy and fortune in early modern France. This study of members of the wider Montmorency family in the sixteenth and early seventeenth centuries demonstrates the financial and political benefits derived from female benefice holding. Abbey stewards and surintendants of aristocratic households collaborated in the administration of religious revenues. Montmorency control of Sainte Trinité, the Abbaye aux Dames, Caen, for over a century was associated with attempts to assert political influence in Normandy. Conflict ostensibly over religious reform could have a political dimension. Yet reform could be pursued vigorously by those originally cloistered for mercenary or political reasons.
\end{abstract}

$\mathrm{R}$ ecent studies of early modern nuns have emphasised the importance of family strategy in their experience. Dynasticism within convents and enforced monachisation of women to preserve family inheritances are two aspects of this strategy evident in early modern Italy, particularly Tuscany; in sixteenth-century France, the importance of female networks centred on abbeys has been noted as a significant dimension of aristocratic patronage. Such phenomena were not incompatible with reform in female religious orders which, in the context of early modern France, embraces both the impact of Protestantism and renewal of Catholic devotion. ${ }^{1}$ This survey of nuns from the extended Montmorency family in the sixteenth and early seventeenth

AMC, L = Archives du Musée Condé Chantilly, series L; AN = Archives nationales; BN, Ms Fr. = Bibliothèque nationale, Manuscrit français; $D B F=$ Dictionnaire de biographie

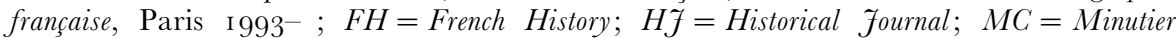
Central; $M S A \mathcal{N}=$ Mémoires de la Société des antiquaires de Normandie; $R H=$ Revue historique

1 S. Evangelisti, 'Wives, widows and brides of Christ: marriage and the convent in the historiography of early modern Italy', Hf xliii (2000), 233-47; J. Baker, 'Female monasticism and family strategy: the Guises and St Pierre de Reims', Sixteenth Century Fournal xxviii (r997), I09I-I08; C. Blaisdell, 'Religion, gender and class: nuns and authority in early modern France', in M. Wolfe (ed.), Changing identities in early modern France, Durham, NG i 997, I47-68. 
centuries illustrates the interaction of these various influences on the experiences of individual women and girls drawn to, or compelled towards, religious life, highlighting their role in their families' political destiny and financial fortune.

For an aristocratic family in early modern France, the acquisition of benefices could be as significant in its strategy, both financial and political, as land purchase or the cultivation of propitious links through marriage. Although the Montmorencys were not to be compared with the Guises, their great political rivals, as a major ecclesiastical dynasty in sixteenth-century France, they controlled some significant benefices. ${ }^{2}$ For the Montmorencys, the female religious were even more significant than for the Guise clan: no legitimate males entered the Church, beyond Philippe de Montmorency, bishop of Limoges in I5I7, and his nephew Odet de Coligny, bishop of Beauvais, archbishop of Toulouse and cardinal de Châtillon in I 533. Demography played its part. When the bishop of Limoges died in I5I9, his two surviving brothers were unmarried and only Anne, future constable of France, would have children. The constable's five sons and seven daughters failed to imitate the procreative vigour of their parents; if patrimonial interests shaped religious destiny, then this reproductive deficit was significant. Three daughters of Anne duc de Montmorency were nuns but, of his fourteen legitimate grandchildren who survived infancy, only one grand-daughter entered religion. Religious conviction also intervened: the offspring of Anne's sister Louise de Montmorency, including her son the cardinal de Châtillon, inclined to Protestantism, as did several of Anne's grandchildren including Henri vicomte de Turenne and the La Trémoille family. Nuns, nevertheless, had a significant contribution to make to the political and financial health of the family.

The financial contribution was most obvious in the much smaller dowries for daughters entering religion rather than marrying. Two of constable Anne de Montmorency's sisters married: Louise's dowry for her first marriage to Ferry de Mailly in I 5 I I was 24,00o livres, while Anne's husband Guy comte de Laval received 40,00o livres in I 5 I 7 . Their nieces, daughters of constable Anne, had 50,00o livres and, in one case, 70,000 livres on marriage; in the next generation, the three daughters of Henri duc de Montmorency were each dowered with $45^{\mathrm{O}, \text { ooo }}$ livres. ${ }^{3}$ Details of the costs of religious life survive only for daughters of Anne de

\footnotetext{
2 The author is studying the ecclesiastical patronage of Henri I duc de Montmorency; for a preliminary survey see M. Greengrass, 'Aristocracy and episcopacy at the end of the wars of religion: the duke of Montmorency and the bishoprics of Languedoc', Miscellanea Historiae Ecclesiasticae viii (I987), 356-63. For the Guise family see Baker, 'Female monasticism', I097-Ioo; J. Bergin, 'The Guise and their benefices, I588-I64I', EHR xcix (I984), 34-58.

3 A. Du Chesne, Histoire généalogique de la maison de Montmorency et de Laval, Paris i624,
} 
Montmorency but a similar ratio probably existed in all three generations between the expenses of making daughters brides of Christ or of fellow aristocrats. When Anne and his brother agreed a partage of their inheritance in 1552 , their sister Marie, a member of the order of Fontevrault, was accorded fifty liores a year; she also received ioo écus d'or on their father's death in I53 I. The I 564 partage of the property of Anne de Montmorency and his wife Madeleine de Savoie allocated capital of 3,000 écus to each of their married daughters but only 500 écus to the nuns, who received annual pensions of ioo livres. ${ }^{4}$

This differential was notoriously exploited in the disinheritance of constable Anne de Montmorency's grand-daughter Françoise de Foix by her brother-in-law Jean-Louis de La Valette duc d'Épernon. While Marguerite de Foix brought her husband some 80,0oo livres a year in I 587 , Françoise received a pension of I, 800 livres. She made her first vows at Angoulême in I 590, aged about eighteen, and was professed at Saintes in I 59 I ; both towns were in Épernon's governorship. Under protest, in I60o she became abbess of St Glossinde at Metz, another of Épernon's governorships. Three years later she fled, suing her brother-in-law for her fortune. The king thereupon committed her to the custody of her uncle, constable Henri de Montmorency. Disinclined to accept responsibility, he tried to persuade the prioress of Poissy to shelter her; she roundly refused, citing the rule of her Dominican order. Sent back by the king to religious life at the abbey of Moncel in i605, Françoise anxiously excused her delayed reception to her uncle: she was not disobedient but the abbess declined to give her the veil until Easter. Finally released from her vows in i6 6 o, she turned Protestant late in i6 I , renewing her lawsuit against Épernon; again she failed, keeping only her original pension and a further 2, ooo livres off the revenues of St Glossinde, while the abbey itself went to Épernon's illegitimate daughter Louise. ${ }^{5}$ Henri de Montmorency's lack of sympathy for a niece who embarrassed a fellow aristocrat was entirely consistent with his ruthlessness towards his own sister-in-law, to keep control of a 'family' abbey, Sainte Trinité at Caen.

preuves, at pp. 268-9; J. Davies, 'Politics of the marriage bed: matrimony and the Montmorency family, I527-г6г2', FH vi (г992), 63-95; B. Bedos Rezak, Anne de Montmorency, seigneur de la renaissance, Paris i 990, 39-67.

4 Partages, i9 Sept. I522, 2 I Jan. I563/4: Duchesne, Histoire généalogique, preuves, at pp. $272,290^{-} 3$.

${ }^{5} \mathrm{P}$. de Guibourgs [Anselme], Histoire généalogique et chronologique de la maison royale de France, Paris I 726-33, iii. 386; G. Girard, Histoire de la vie du duc d'Espernon, Paris I655, I 730 edn, 56-7; Henri Iv to Montmorency, 6 Aug. I603, in Lettres missives, ed. B. de Xivrey and J. Guadet, Paris I 843-76, vi. I 47-8; Jeanne de Gondi to Montmorency, Sept. I603, AMC, L lxxiii, fo.ı 3; Françoise de Foix to Montmorency, 25 Mar. i6o5, AMC, L lxxx, fo. 259. Compared with Charlotte de Bourbon-Montpensier's conversion and flight from her abbey of Jouarre in I57 I, Françoise's adoption of Protestantism seems expedient. 
Françoise de Foix's experience was, however, an extreme: entry into religious life imposed for entirely financial motives, followed by outright rejection of the Catholic faith. The commitment of most other women in the wider Montmorency family to religious life seems to have been less cynical or, at least ultimately, spiritually more satisfactory; political and financial motives cannot, however, be entirely dismissed. Marie de Montmorency, sister of constable Anne, entered religious life at Wariville in the diocese of Beauvais which was held by a succession of bishops with Montmorency connections. In I 529 she became abbess of the Cistercian house of Maubuisson where her two immediate predecessors had links to her family. Henriette de Villiers, abbess from i 525, was related to Marie's maternal grandmother and to Charles bishop of Beauvais who gifted the Villiers lands to Marie's brother Anne in I527. The previous abbess, Antoinette de Dinteville, was second cousin of Marie's mother; and her brother or nephew, Françoise de Dinteville, bishop of Auxerre, was depicted in the stained glass of the Montmorency family mausoleum at St Martin de Montmorency. ${ }^{6}$ When Marie de Montmorency died in I 543, her brother Anne was politically disgraced and Maubuisson passed successively to relations of his political enemies, admiral d'Annebault and the duchesse d'Étampes. By autumn i56o, however, a vacancy was expected. Noting Maubuisson's wealth and its earlier Montmorency link, the queen mother offered to secure it for the constable's daughter Louise, a nun at St Pierre de Reims. But the incumbent abbess survived until I574, the moment passed, and Maubuisson never returned to the Montmorency family. ${ }^{7}$ The episode, none the less, clearly demonstrated the principle of 'family' benefices.

The Montmorencys were the pivotal link in another family succession at the Benedictine house of St Pierre d'Avenay in the diocese of Reims, although no abbess bore their name. The abbess from i 576 was Françoise de La Marck, sister of Henri duc de Montmorency's first wife. Her successor was her great-niece, daughter of Marguerite de Montmorency duchesse de Ventadour; Marie-Françoise de Lévis-Ventadour was named her coadjutrix in I6o6, although still far too young to govern the abbey. Françoise de la Marck began her religious life at St Pierre de Reims by I 569, surrounded by her Aumale first cousins and their Guise relations including the abbess Renée de Lorraine. Later she identified much more

\footnotetext{
${ }^{6}$ Bedos Rezak, Anne de Montmorency, 309, 343; R. Baillargeat, L'Église collégiale Saint Martin de Montmorency, Paris I959, 2 I8; E. A. R. Brown, 'Sodomy, honor, treason and exile: four documents concerning the Dinteville affair (I538-I539)', in J. Fouilleron, G. Le Thiec and H. Michel (eds), Sociétés et idéologies des temps modernes, Montpellier i 996, $5^{\text {I I }-32 .}$

7 Marie d' Annebault (I 543-6) and Marie de Pisseleu (I 546-74): Gallia Christiana, vii. 934; R. J. Knecht, Francis I, Cambridge I982, 299-300, 410-I5; Catherine de Médici to Anne de Montmorency, Sept. I 559, in Lettres de Catherine de Médicis, ed. H. de La Ferrière and G. Baguenault de Puchesse, Paris r880-r9o9, i. I25.
} 
closely with her Montmorency connections, firmly rejecting the Catholic League and supporting Henri iv in the early i590s. ${ }^{8}$ She regularly corresponded with her brother-in-law Henri de Montmorency about the young children of his second wife, commiserating on an injury to his son and heir, proposing a husband for his daughter. She enthused about Montmorency's Ventadour grand-daughter Marie-Françoise who moved to Avenay from Chelles in I6o3 at the age of four: 'la plus jolie qui se peult voir et m'a portée en tel amitié que je croy qu'elle prolonge mes jours'. ${ }^{9}$

None the less after Marie-Françoise's arrival, her great-aunt fell dangerously ill and her grandfather Montmorency tried to secure the succession for this small child. His surintendant des affaires Nicolas Girard went to the king at dinner on 2 I December I6o3 to ask for Avenay. But the previous day Henri Iv had granted the abbey to his cousin Marie de BourbonCondé, a nun at Fontevrault, at the request of her aunt the duchesse de Guise. An example of the need to secure benefices as soon as the ill health of an incumbent became known, this was a double rebuff to Montmorency. His own and the abbess's royalist credentials were discounted against the formerly Leaguer madame de Guise, who was also his opponent in a lengthy lawsuit about his Breton lands then before the Paris parlement. Girard dared to argue that abbeys should be reserved for the relatives of abbesses who brought them up, so as to ensure the community's obedience, but the king pointed out that his first concern was for his own relatives. Informed by Girard that the physicians believed the abbess would after all recover, the king responded 'Tant mieux pour elle', refusing to discuss the matter further. ${ }^{10}$ Françoise de La Marck indeed survived to i6o8. The earlier crisis ensured, however, that measures were taken to ensure Marie-Françoise's succession reflecting, according to her great-aunt, the unanimous desire of the entire community. Montmorency's anxiety to secure Avenay may have represented not only concern for his political prestige but also indirectly for his financial wellbeing. His surintendant, closely involved in negotiations about dowry payments with the Ventadours, would have been well aware that securing the future of one of their numerous offspring might moderate their demands. ${ }^{11}$ Although Françoise de La Marck had restored the abbey's material prosperity, it was not until i 6 i i that enclosure - a sign of spiritual reform - was enforced under the regime of Marie-Françoise's successor, after the

8 A. L. Paris, Histoire de l'abbaye d'Avenay, Reims i879, 286-3 I I; Baker, 'Female monasticism', I I I-2.

${ }^{9}$ Françoise de La Marck to Montmorency, 28 Apr., [?] Sept. i6o3, 20 Sept. i6o4: Paris, Histoire d'Avenay, 3 I 7 ; AMC, L lxxiii, fo. I I ; lxxviii, fo. 93.

${ }^{10}$ Girard to Montmorency, 2 I Dec. i6o3, AMC, L lxxiv, fo. i 80.

11 Françoise de La Marck to Montmorency, i6 Dec. I6o3, ibid., fo. I33; Davies, 'Politics of the marriage bed', 86. Montmorency influence obtained the see of Lodève for Marie-Francoise's brothers, Charles, François and Anne between I6o4 and I625, though none was consecrated bishop. 
child abbess exchanged Avenay for St Pierre de Lyon, closer to her family in Vivarais. ${ }^{12}$

Anne, Louise and Madeleine de Montmorency, daughters of Anne duc de Montmorency, were all dedicated to the church at ages varying between six and twenty-six. ${ }^{13}$ Although their vocations were all apparently genuine, even that of Louise who entered religion as a very young child, their careers were dedicated to family interests as well as God. Anne was the first to be professed on 22 July I 547 in the wealthy Benedictine house of Notre Dame du Ronceray at Angers; the associated ceremonies cost almost 400 livres and she was given an annuity of $\mathrm{IoO}$ livres. The choice of Le Ronceray may have been connected to her father's acquisition of extensive estates in Anjou and Brittany in I540 by a donation subject to lengthy legal challenges. An additional motive is suggested by the twenty-year-old Anne's accession as abbess in I 549, apparently the first royal nomination under the Concordat of Bologna, although the nuncio congratulated her father that she had been chosen by the community without 'abuses'. Anne's rule continued unremarkably, undistinguished by any reform, until she departed to rule the Abbaye aux Dames at Caen in I $555 .{ }^{14}$

Louise entered St Pierre de Reims on i6 August i550. Madeleine de Savoie answered for her six-year-old daughter on her reception into the abbey which received a gift of 300 livres and a lifetime annuity of a oo livres. Surviving correspondence about Louise's profession in I 559, suggests that this step was undertaken at her own volition. In the spring of $\mathrm{I} 55^{8}$, when Louise was probably fourteen, her first cousin Cardinal de Châtillon was involved in obtaining Henri II's approval for the intentions of a daughter of madame la connétable, 'veu la dévotion de vostre fille à la religion'. ${ }^{15}$

12 Paris, Histoire d'Avenay, 3 I9-2 I, 337; S. Olive (ed.), Archives du château de Léran, Toulouse igo3-I 2, iv. 373-4.

13 Genealogists rarely recorded females' dates of birth. F. Decrue de Stoutz, Anne duc de Montmorency connétable et pair de France sous les rois Henri II, François II et Charles IX, Paris I 889, 396, claims that the three nuns were born after I544. A study of the I 544 stained glass portraits of the constable's children suggests that the second daughter, born in 1529 , was Anne and Louise was the youngest, with Madeleine and Marie, who married in $5^{6} 67$, yet to be born: F. Perrot, 'Vitraux', Le Musée Condé (1973), i 84-8. But Madeleine, aged fifty-nine in 1597 , must be among the five daughters in the window, so Louise, aged six in I550, and Marie were born too late for inclusion.

${ }^{14}$ L. J. V. Brétaudeau, Notre Dame du Ronceray, Angers 1895, 180-2; Della Torre to Cardinal Farnese, i 3 Nov. I549, in Acta nuntiaturae gallicae, Rome ig6 I- . vi, 447. For accounts for the sisters' entries into religion see AMC, A carton I. For Montmorency lands see Bedos Rezak, Anne de Montmorency, 22-38, and Mark Greengrass, 'Property and politics in sixteenth-century France: the landed fortune of constable Anne de Montmorency', FH ii ( 1988$), 37 \mathrm{I}-98$.

${ }^{15}$ Odet de Coligny to Madeleine de Savoie, [late Mar. I558], in 'Correspondance d'Odet de Coligny cardinal de Châtillon I 537-68', ed. L. Marlet, in Documents publiés par la Société historique et archéologique du Gâtinais i (I885), 37-8. 
By September I $55^{8}$, having been given time for reflection at her mother's request, Louise was determined to take her final vows, if possible in the presence of her parents who had acceded to her wishes. Abbess Renée de Lorraine sent details of the appropriate ceremonial to Madeleine de Savoie though these do not survive. ${ }^{16}$ With her father in Spanish hands after the battle of St Quentin in I 557 until November I558, Louise's profession was deferred to the feast of St Barnabas ( I June) i 559. Even so, her parents were absent but her maternal aunt Isabeau de Savoie, comtesse de Bouchage, attended and could bear witness to the young nun's virtuous and devout commitment and all the solemnities of the day. Tempting though it may be to suspect that 'the lady doth protest too much', Louise's vocation appears to have been entirely genuine. Two years after her profession, the cardinal de Lorraine, brother of Abbess Renée, remarked on her devotion to her father: 'au demeurant, Monsieur, je ne veulx oublié à vous dire que vous avez icy une fille autant vertueuse et qui faict si bien son debvoir que vous avez grande occasion d'estre bien content d'elle'. ${ }^{17}$ The choice of St Pierre for the constable's daughter remains puzzling, given the abbey's close identification with the Guises, rivals or even enemies of the Montmorencys; but perhaps it is a salutary reminder to avoid mechanical assumptions about family and political allegiances at this period. ${ }^{18}$

Full details of the ceremonies for Louise's profession do not survive, but some indications remain of those expected for her older sister Madeleine at Fontevrault. Madeleine herself provided her maternal uncle Honorat de Savoie marquis de Villars with a memorandum of what would be needed, including hangings of cloth of silver for the chapel. Decorations had also been provided at Reims for Louise's profession, reminding the community to pray for the constable and his wife, as Renée de Lorraine gratefully acknowledged. Besides the cloth of silver, Madeleine also mentioned thirty ells of linen, eight ells of green cloth, a silver basin, jewels

16 'Suivant ce que je vous avois dernièrement escript, et sur ce avoir eu responce, j'ay donné encores quelque temps à vostre fille ma Religieuse pour bien et discrettement pencer à ce que sy, pertinement, elle m'a supplié despuis qu'elle cest veneue sur son aage de pouvoir fair profession de son estat, en quoy je la tiens heureuse que Nostre Seigneur luy a continué cette première voullonté de sa ieunesse': Renée de Lorraine to Madeleine de Savoie, 5,7 Sept. I558, BN, ms Fr. г 0239, fos 31, 33. Professor Joseph Bergin kindly transcribed these letters.

17 Renée de Lorraine to Madeleine de Savoie, 25 May I 559, BN, ms Fr. 3260, fo. I I 3 , and I 2 June I559, Ms Fr. I0239, fo. 36; Charles de Lorraine to Anne de Montmorency, i 8 Nov. I56 I, in Lettres du Cardinal Charles de Lorraine 1525-1574, ed. D. Cuisiat, Geneva I $998,442-3$.

18 Baker, 'Female monasticism', i i 02, notes the connection between Françoise de La Marck and Louise de Montmorency, but Louise had entered St Pierre almost nine years before her brother Henri married Antoinette de La Marck in January i 559; discussions about her profession there began months before the negotiations for her brother's marriage. 
for the abbess and her nieces and a banquet for the community at Fontevrault. She pointed out that in this aristocratic house all 'filles de bonnes maisons' brought at least 200 écus d'or at their profession so she could hardly bring less. Ultimately Madeleine's profession, on 24 July I564 when she was twenty-six, cost I,00o écus, seven times the sum expended on her sister Anne at Le Ronceray seventeen years earlier. Madeleine also asked her uncle for a further sixty livres of pension in addition to the ioo livres accorded by her parents to their daughters in religion. ${ }^{19}$ Since Villars's sister Isabeau had represented Louise de Montmorency's family at her profession, the maternal kin of nuns may have had a significant role to play in their dedication to religion. ${ }^{20}$ Madeleine's appeal to her uncle may, however, have been a shrewd calculation of his disposable income, given that he was the father of an only child, a daughter already married.

Louise de Mailly, first cousin of the Montmorency sisters, was a rare female pluralist, abbess of the Cistercian house of Lys near Melun in the diocese of Sens as well as holding the Benedictine abbey of Sainte Trinité at Caen on her death in I 554. She was named to Caen by François I in I533, almost certainly at the instigation of her uncle Anne de Montmorency. Then high in royal favour, he had taken responsibility for his sister Louise's family after her second widowing in I522; Louise de Mailly's half-brother the cardinal de Châtillon owed his benefices to their uncle's patronage. Nothing is known of her religious life before I 533 but, like her sister Madeleine and probably their mother, she was sympathetic in some degree to Protestant reform. On her mother's death in I 547, she requested verses from Théodore de Bèze shortly before his departure for Geneva; and her own epitaph by Ronsard, while highlighting her family connections, emphasised Christ's merits as her hope of salvation. ${ }^{21}$ Even more significant than Louise de Mailly's intriguing religious sympathies

19 For the elaborate ceremonies associated with entry into religious life see K. J. P. Lowe, 'Secular brides and convent brides: wedding ceremonies in Italy during the Renaissance and Counter-Reformation', in T. Dean and K. J. P. Lowe (eds), Marriage in

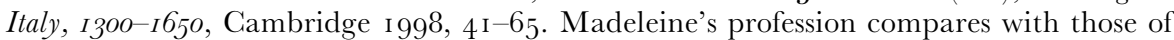
a daughter of Henri I duc de Guise in 1596 and a natural daughter of the comte de Soissons in I603. Jeanne de Lorraine brought chapel decorations in cloth of gold, zoo écus, a pension of 100 écus to the community and 50 écus a year for her own maintenance; Charlotte de Soissons's dowry was similar: S. Poignant, L'Abbaye de Fontevrault et les filles de Louis XV, Paris i $966,73$.

20 The significance of matrilineages for Italian nuns is noted by Lowe, 'Secular brides', 59-6o.

21 'Épitre consolatoire de Théodore de Bèze à l'amiral de Coligny sur la mort de sa femme, 27 juin I 568', Bulletin de la Société de l'histoire du protestantisme français xxvi (1877), $45^{6-6}$ I at p. 460. Bèze refers to French verses commissioned by madame de Caen which were inscribed in the Coligny family chapel at Châtillon: P. Ronsard, Oeuvres complètes, ed. G. Cohen, Paris I 950, ii. 5 I 7-i 8. Her three Coligny half-brothers were Protestant leaders until I 572 ; her sister, the comtesse de Roye, was a Protestant activist and mother-in-law of 
was her status as first in a dynastic sequence of Montmorency-connected abbesses of Caen, which continued until i $65^{0}$.

A royal foundation, Caen was subject to the ${ }_{5}{ }_{1} 6$ Concordat giving the right of nomination to the crown. Immediately after Louise de Mailly's funeral service, the community wrote to both Henry II and the constable requesting the nomination of Anne de Montmorency, abbess of Le Ronceray. This initiative may have been a covert survival of the superseded election, but the nuns fully intended their petition to win them the favour of king and constable. Citing Anne's singular virtue, they declared that a family succession would ensure charity and friendship in their house - anticipating the arguments used by Nicolas Girard to Henri iv when he tried to secure Marie-Françoise de Lévis-Ventadour's succession to Avenay in i6o3. On I4 August I554, eleven days after Louise de Mailly's death, the constable's secretary duly arrived with the royal letters nominating Anne de Montmorency. In the year before she took possession of Sainte Trinité, the nuns urged the constable several times to hasten her arrival. Her entry to Caen on 25 August I555 emphasised her family connections. Provided with a large escort of gentlemen by her father, Anne and her companions from Le Ronceray were joyfully greeted by 200 gentlemen, judges and bourgeois of Caen. They expressly recognised in the new abbess a conduit to the patronage of her father and other aristocratic relations. ${ }^{22}$ The dynastic principle was reinforced by Louise de Montmorency's transfer from Reims as coadjutrix to Anne, her senior by some fifteen years; the date of her arrival in Caen is unknown but its purpose was frustrated by her death on 7 July i 588 , just twenty-two days before Anne's demise. ${ }^{23}$

Madeleine de Montmorency's succession was a dynastic but also a political event, since her sisters' deaths coincided with the climactic crisis of Henri III's troubled reign. ${ }^{24}$ After the Day of the Barricades in Paris on I 2 May I 588, the king first retreated to Normandy. Though negotiating with the duc de Guise, leader of the Catholic League, the king sought reconciliation with Henri duc de Montmorency, brother of the abbess of Caen, in order to maintain links to his ally Henri of Navarre, the Protestant leader and heir to the throne. Although the king did not make his main concessions to Montmorency until the turn of the year, in August I 588 he was already making significant gestures, encouraging political marriages for Madeleine's nieces. Madeleine's nomination may therefore

two militant Protestants, Condé and La Rochefoucauld. For Louise de Mailly's mother, sister and nieces see N. L. Roelker, 'The role of noblewomen in the French Reformation', Archiv für Reformationsgeschichte lxii (1972), I68-95.

${ }^{22} \mathrm{BL}$, ms Harley $3^{66} \mathrm{I}$, fos $3^{6-9}$. This description of Anne's nomination and entry is decorated with illuminated initial letters incorporating the Montmorency arms.

${ }^{23}$ Gallia Christiana, xi. 436 .

24 Abbess of Gercy since I576, Madeleine apparently kept the revenues of this Benedictine house, granting her successor a pension of 600 liores: ibid. vii. 627. 


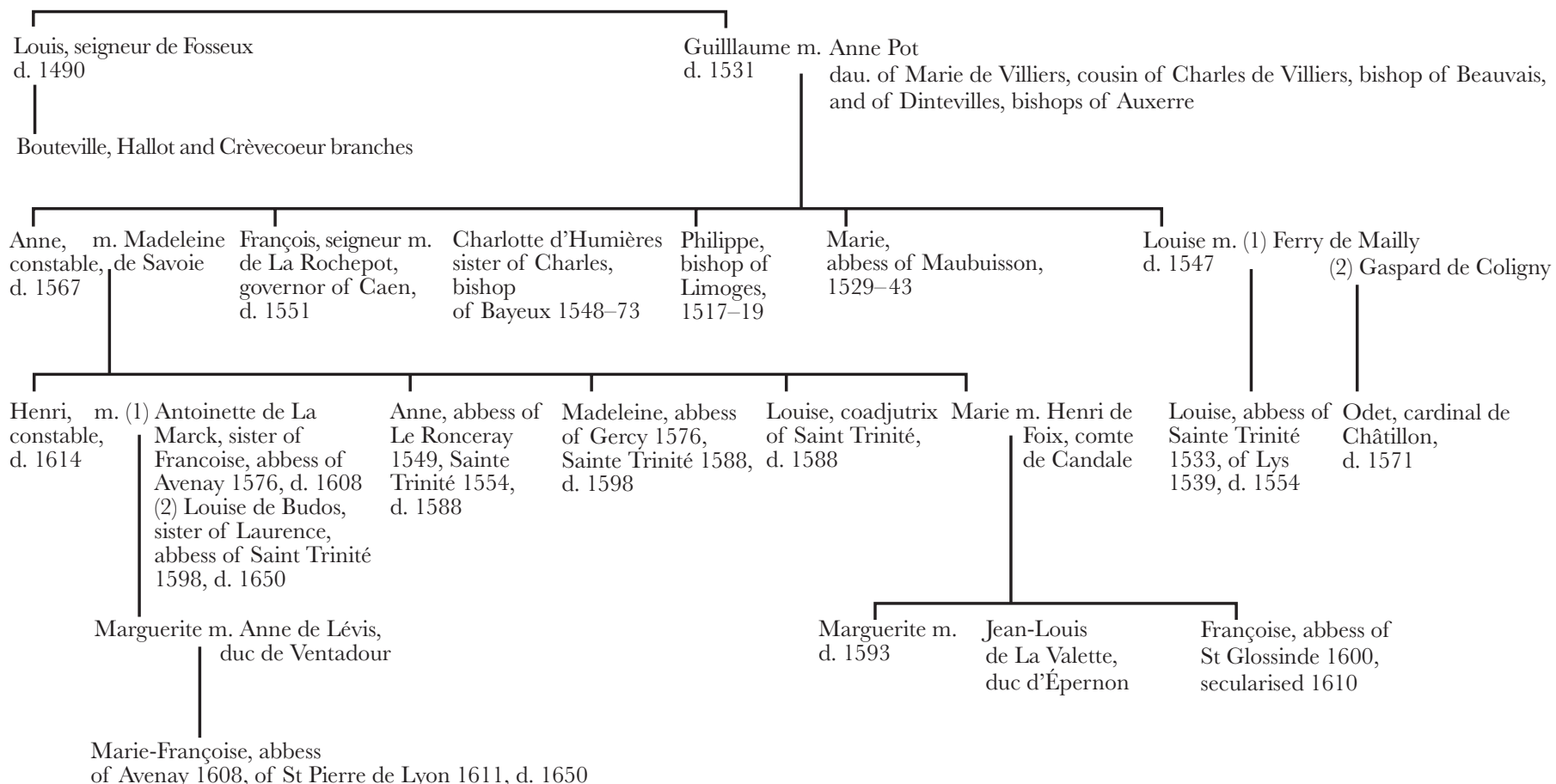

Fig I. The Montmorency family: abbreviated genealogy, showing female religious 
be seen as a harbinger of Henri III's rapprochement with her brother. ${ }^{25}$ Madeleine's tenure saw the dynastic principle embodied in a magnificent tomb in the abbey church, eventually housing all three sisters, which she and her brother, as head of the family, commissioned in $1592 .{ }^{26}$ When demography compromised this principle, Laurence de Budos, sister of Henri de Montmorency's second wife, was propelled into the succession in I 598, governing the abbey until her death in $165^{\circ}$.

Henri de Montmorency had a direct financial interest in Sainte Trinité, perhaps acquired on his sister Madeleine's succession, perhaps an inheritance dating back to his cousin Louise de Mailly's abbacy; clear evidence for his pension from the revenues emerges only from I 599 but his agents were earlier involved with the abbey's administration. Although the abbey was notably wealthy for a female house, its cash flow in the late sixteenth century was restricted and Montmorency intervened with the royal commissioner engaged in the 'régalement' of the taille in favour of parishes dependent on the abbey. ${ }^{27}$ The community had to borrow some 2,500 écus from its steward Jacques Barrin in I 597, a debt not repaid until I604; and, when Montmorency himself required money urgently, Barrin could send only i 50 écus with one of the abbey's receveurs because of the expenses of Madeleine's funeral. ${ }^{28}$ Jacques Barrin, canon of the Sainte Chapelle and prior of La Tour du Lay in the diocese of Beauvais, though the abbey steward, was primarily a Montmorency agent. He was expected to secure payments from the crown to Montmorency assigned on the Caen généralité in 1595 and his advice was sought about a new

${ }^{25}$ J. Davies, 'Neither politique nor patriot? Henri I, duc de Montmorency and Philip II, I 582-I 589', H7 xxiv (I99I), 539-66. The king wrote several times to his ambassador in Rome seeking Sixtus v's intercession with Montmorency: Henri iII to Pisany, 2 Aug., 25 Sept. I 588 . BN, ms nouvelles acquistions françaises 2743 , fos I $74^{-} 5$, I $87-8$.

${ }^{26}$ Anne's coffin was discovered in 1854 under the crossing tower. The tomb was inscribed with verses for each sister; Anne: 'Trente ans et plus je tiens ce lieu/ Sois-tu pour le moins en ma place/Ma chère soeur autant d'espace/Avant que de venir à Dieu'; Louise: 'Madeleine, mon cher soucy/Ainsi me puisses-tu survivre/Comme tu fais icy revivre/Les deux soeurs de Montmorency'; Madeleine: 'Ce monde mépriser, ne dépriser personne/Et d'estre méprisée ici bas mépriser/Se mépriser soi-même en ayant l'âme bonne/Sont des vertus qui font Madeleine priser': A. Charma, 'Note sur une découverte faite dans l'église Sainte-Trinité', $M S A \mathcal{N}$ 3rd ser. ii ( 1858), I $37-40$.

27 Barrin to Montmorency, 26 June I 599, AMC, L xlviii, fo. 287. The abbey's records, occupying eleven metres of shelving in the Archives départementales of Calvados, are not inventoried. An impression of its sixteenth-century wealth may be derived from medieval evidence in Charter and custumals of the abbey of Holy Trinity Caen, part 2, ed. J. Walmsley, Oxford i994. I am grateful to Professor Walmsley for his advice about the abbey's archives. In I 768 its annual revenue was 55,00o livres, compared with 25,000 livres for both Avenay and Le Ronceray, and merely 6,ooo livres for Gercy, held by Madeleine before her move to Caen: A. Peigné-Delacourt, Tableau des abbayes, liste des abbayes royales des filles, Arras-Paris I875, 73-9.

${ }^{28}$ Barrin to Montmorency, [Jan. I 599], AMC, L xxxiv, fo. 249; settlement with Barrin, Mar. i6o4, AN, MC viII 563 , fo. 20 I. 
$676 \quad$ JOAN DAVIES

governor for Caen in I598. While Montmorency's other servants trusted him, they thought he occasionally needed a touch of the spur with letters 'en maitre' from Montmorency. ${ }^{29}$ Jacques's uncle, and predecessor at the Sainte Chapelle, Toussaint Barrin, had been constable Anne's secretary, deeply involved in his financial affairs and recipient of his ecclesiastical patronage; could he have been the secretary who brought Abbess Anne's nomination to Caen in I554? Appointed to Henri de Montmorency's Paris council in I578, Toussaint administered the estate of Henri's elder brother François on his death in I579. A tenant of Sainte Trinité at Merville in I $57 \mathrm{I}$, ten years later he was buried by his express request at Gercy, then governed by Madeleine de Montmorency. His great-niece Michelle Barrin, a nun at Gercy, transferred to Caen with Madeleine in I 588, confirming the Barrins's client relationship with the Montmorencys. ${ }^{30}$

Jacques Barrin's role as defender of dynastic interests clearly emerged when Madeleine de Montmorency's health failed from spring I597. Although permitted by the legate to eat meat and regularly attended by her brother's physician François Ranchin, skilled in the kidney ailments common in the family, she died on io December I598. ${ }^{31}$ When her symptoms first appeared, Barrin urged both Montmorency and his wife Louise de Budos to secure the succession. Henri iv proved more compliant in 1597 than six years later for Avenay, when Montmorency's political star had waned. At the siege of Amiens, where Montmorency loyally served alongside him, the king granted his brevet de réserve to his sister-inlaw Laurence de Budos. Although others petitioned the royal mistress Gabrielle d'Estrées when Madeleine's decline became known, the king confirmed his promise just a week after her death. ${ }^{32}$ Laurence de Budos was, however, only twelve years old in ${ }^{5} 598$ and reluctant to take the veil.

${ }^{29}$ Jean Girard to Montmorency, i 7 Oct. I 595, AMC, L xxiv, fos i68-9; Forestier to Montmorency, 20 Apr. I598, xl, fo. 266; Ranchin to Montmorency, [I599], AMC, L xxxiv, fo. 248 .

${ }^{30}$ R. R. Harding, 'The provincial governors of Reformation France: the anatomy of a power elite I542-I635, unpubl. PhD diss. Yale i974, 297. Toussaint was abbot of Ferrières in the diocese of Sens, St Lo in Coutances and St Maurice in Quimper. See procurations of Henri de Montmorency and of Madeleine de Savoie and Diane de France: i Mar. I578, BN, ms Fr. 23155, fo. I82; 9 May i579, AN, MG vili iog, fo. 6; A. L. Léchaudé d'Anisy, 'Les Anciennes Abbayes de Normandie', $M S A \mathcal{N}$ ist ser. viii (i834), 220; Toussaint Barrin's will, 26 Apr. I58 I, AN, Y I22, fo. 449. For the novice mistress Michelle Barrin, substitution of annuity, 23 Oct. I599, see AN, MG viII 419, fo. 429.

${ }^{31}$ For details of her illness see Barrin to Montmorency, i9 Apr. I597, 8 Aug., 4 Oct., 24 Nov., 5, го Dec. I 598, AMC, L xxxii, fo. 25 I ; xliii, fos 33, I 9 I ; xliv, fo. 206 ; xlv, fos 25, 56; Ranchin to Montmorency, xlii, fo. 300 bis; xlix, fo. I59.

${ }_{32}$ Barrin to the duchesse de Montmorency and Montmorency, ig Apr. I597, AMC, L xxii, fos 249, 25 I ; Ranchin to Montmorency, 30 July I 598, xlii, fo. 300 bis. Royal letters, [c. June-Sept] I597, I 7 Dec. I598, in Léchaudé d' Anisy, 'Les Anciennes Abbayes', $377^{-8 .}$ 
Montmorency soon received requests for the abbey, acknowledging his effective possession. A distant relative, madame de MontmorencyBouteville, well-informed as sister-in-law of Caen's governor Jacques de Montmorency-Crèvecoeur, swiftly wrote for her own sister Luce de Luxe who was already a nun, promising whatever pension was required to Montmorency and to his son after him. The Boutevilles persisted in I 599, suggesting a pension of 2,500 écus, nominally for Montmorency's fiveyear-old daughter to whom the abbey would devolve on the death of Luce de Luxe. An offer of 50,00o écus was received which, if from the Boutevilles, capitalised their proposed pension at twenty years' purchase. $^{33}$

These offers were utilised by Montmorency and his advisers in fraught negotiations about the dowries of his second and third wives, the sister and aunt of the putative abbess. In November I599, two months after his clandestine marriage to Laurence de Clermont, the aunt of Louise and Laurence de Budos, he accepted a pension of only 2,00o écus, disguised as a rente purchased for 24,000 écus from his mother/sister-in-law, Catherine de Clermont, vicomtesse de Portes. This was paid, often in arrears, until I603 when the rente was recognised as fictitious. Laurence de Budos had given Montmorency a signed promise to resign the abbey only to his daughter Charlotte-Marguerite who would receive 2,00o écus annually for her maintenance, while she was unmarried; this pension was actually extinguished six years before her i6o9 marriage. Although Barrin had already encountered problems in raising cash at Caen, Montmorency was infuriated by the vicomtesse de Portes's delays in paying this pension. ${ }^{34}$ Lawyers were consulted in the summer of 1603 but within two months matters were settled without resort to the courts. No longer able to rely on royal support, as evidenced by his difficulties over Avenay, Montmorency was perhaps experiencing the pangs of conscience which led him to seek papal absolution for enjoying some Ioo,ooo écus in church revenues. ${ }^{35}$

Beyond acknowledgment of the fictitious rente, the details of this settlement are obscure. Montmorency probably surrendered Laurence de Budos's promise of resignation. His surintendant Girard asked for this to be sent to Paris, with a letter requesting Harlay, premier président of the

${ }^{33}$ Charlotte de Luxe to Montmorency, Dec. I598, AMC, L xlv, fo. I 26; draft brevet for Luce de Luxe, with pension for Henriette [sic] de Montmorency, Sept. I 599, li, fo. 208; Girard to Montmorency, I5 Sept. I 599, I, fo. 2.

34 Purchase and cancellation of rente, 3 Nov. I 599, I 8 Aug. I6o3, AN, MG LIV 453, fo. 353; LIV 46I. Arrears: Catherine de Clermont sending 500 écus from Caen to Montmorency, I 3 Mar. I6o2, AMC, L lxiv, fo. 77; Girard to Montmorency, 4 Sept. I6o2, lxvii, fo. io. In I6o i Montmorency tried to compel his rejected third wife, Laurence de Clermont, to retire to the abbey with her niece. For his marital problems see Davies, 'The politics of the marriage bed', $76-82$.

${ }_{35}$ For Montmorency's church revenues see J. Bergin, The making of the French episcopate i 589-i66 I, New Haven-London i 996, i 53. 
$678 \quad$ JOAN DAVIES

parlement, to produce a sealed packet previously entrusted to him by Montmorency and madame de Portes; these documents, presumably containing the true details of their original agreement about the abbey, were burned in the presence of Harlay and the vicomtesse after the settlement was reached. After some confusion, another packet entrusted to the premier président of Grenoble was similarly destroyed in the presence of Antoine-Hercule de Budos and the baron de Dismieu, the son and son-inlaw of the vicomtesse. ${ }^{36}$ Laurence de Budos's biographer gave a rather different account of the termination of the Montmorency pension, promoting the young abbess's reforming intentions. Just before she took her final vows, Laurence allegedly begged the king to end this obligation or take back the abbey; charmed by the fifteen-year-old abbess, Henri Iv required Montmorency to surrender his claims. While the king's susceptibility is plausible, given his attraction to Laurence's sister Louise when she arrived at court in 1595 and his grand passion in I6og for her niece Charlotte-Marguerite de Montmorency, the anecdote is contradicted by the archival evidence of the I603 negotiations, a year after Laurence's profession. Furthermore Henri Iv actually advised Girard to ensure that the I603 settlement allowed the succession to the abbey to be reserved for Montmorency's daughter. ${ }^{37}$

Jacques Barrin's dual role as abbey steward and protector of dynastic interests was demonstrated during the problematic period when Laurence de Budos was slowly persuaded to accept her destiny. He had already requested Montmorency's orders in the event of Madeleine's death and he argued for Laurence's immediate installation as abbess. Acknowledging the impropriety of her taking possession in secular dress, he recommended that she proceed from novitiate to profession within two days and despatched the garments necessary for her vesture. This took place at the abbey of Chelles near Paris, since Barrin advised that an abbess should not make vows in the house she governed, but she was not professed until i 602 at the more respectable age, canonically, of sixteen, having desired it for over a year. ${ }^{38}$ At first Laurence was pathetically reluctant to embrace

${ }^{36}$ The negotiations can be traced in the correspondence of Girard, Forestier and others with Montmorency, 2, 5, 6, Io July, I 5, 25, 26 Aug. I6o3, AMC, L lxxii, fos 3, I 2, I 3, 2 I-2, 40, I I6, I55, I 77; lxxiii, fo. г 04; Ennemond Rabot d'Illins to Montmorency, 6 Sept., 3 I Oct. I603, lxxiii, fos I I9, 2 I 5.

37 J. Bouette de Blémur, L'Année bénédictine ou les vies des saints de l'ordre de Saint Benoît, Paris I 667-73, ii. 266-86; Girard to Castillon, [го July г603], AMC, L lxxii, fo. io4.

${ }^{38}$ Barrin to Montmorency, 4 Oct. I598, [Jan. I 599], AMC, L xliii, fo. I 9 I ; xxxiv, fo. 249. Catherine de Clermont to Montmorency, [June I602], lxv, fo. 228; J. B. Elzière, Histoire des Budos, Aix-en-Provence I 978, г 22-4. The Council of Trent required eight years between profession and becoming abbess, an office reserved for those aged forty or above; more generally, two years in the novitiate should precede profession, which should not take place before the age of sixteen: R. Taveneaux, Le Catholicisme dans la France classique, Paris I 980, i. 69-70; E. Rapley, 'Women and religious vocation in seventeenth-century France', French Historical Studies xviii (r 994), 6r 3-29 at p. 6r 9. 
religious life and the responsibilities of abbess. Entering Sainte Trinité at Candlemas I 599, she dreaded abandonment by her relations and begged Montmorency to order Barrin to remain at Caen until her mother arrived, since she would rather die than be left alone at the abbey. ${ }^{39}$ Uncertainties about whether she had indeed quit the cloister became a factor in the negotiations with her mother and aunt about the pension expected by Montmorency from the abbey. Her mother had wanted to delay her taking the veil until the bulls were received, but then became increasingly anxious that her daughter would change her mind completely. Montmorency let it be known that he could not understand Laurence's hesitation since, if God had given him a second daughter, he would have installed her most honourably in the abbey. This was a disingenuous observation, given that he had three legitimate daughters, the two older already married..$^{40}$ But Laurence's initial fears evolved into a vocation, even enthusiasm. While the termination of Montmorency's pension in 1603 made Barrin's presence redundant, his retreat may also have been linked to Laurence's growing confidence and reforming zeal; if her biographer may be believed, after finding important documents abandoned in a barn, she denounced the steward who had served her predecessor in a humiliating tirade. ${ }^{41}$

Laurence de Budos's spiritual development poses problems for a simple equation of lay aristocratic patronage with lack of reform. Before her profession, Laurence promised the vicar-general of Bayeux that she would introduce reform into the community, soon afterwards visiting Benedictine houses such as Montmartre and Montivilliers which provided examples of good governance. Certainly the effectiveness of her predecessors, the Montmorency abbesses, may be doubted: some rebuilding and a new breviary were their legacy. Almost a century elapsed between Isabeau de Bourbon's attempts to impose a more rigorous rule in I 5 I 5 and Laurence de Budos's refusal to admit her mother and brother on Palm Sunday or Corpus Christi i6 ro, an echo of the 'journée du guichet' at Port-Royal in the previous year. ${ }^{42}$ Reform in its Protestant dimension had triggered the departure of sixteen nuns, four to Geneva with the remainder returning to their families; this incident occurred probably during Anne de

\footnotetext{
39 Laurence de Budos to Montmorency [c. May i 599], AMC, L xlviii, fo. i83. Her cousin Jean de Porcellet, seigneur de Maillane, Montmorency's client, anxiously consulted his patron when she asked him to remain with her: I5 Feb. I 599, xlvi, fo. I 33.

${ }^{40}$ Girard to Montmorency, I 5 Sept. I599, AMC, L I, fo. I9I.

${ }^{41}$ Léchaudé d'Anisy, 'Les Anciennes Abbayes', 378; Bouette de Blémur, L'Année bénédictine, 269.

42 A. Sedgwick, The travails of conscience: the Arnauld family and the ancien régime, Cambridge, Mass. I998. Youthful acquisition of abbeys by no means precluded reform as the Arnaulds demonstrated. Antoine Arnauld, father of Mère Angélique, regularly served on Montmorency's Paris council.
} 
Montmorency's tenure but reflected the possibly Protestant sympathies of her predecessor Louise de Mailly. ${ }^{43}$ Madeleine's ten years, two affected by illness, were too brief for effective restoration of a more regular observance. But in striving towards this, she encouraged the departure of recalcitrant nuns including, perhaps, Rachel de La Ménardière who left in I 592 for a priory in the diocese of Chartres. Sister Rachel's case became central to a complex conflict between Montmorency and the community that developed from the arrival of Laurence de Budos in February I 599. ${ }^{44}$

Laurence's youth and doubtful vocation offered the community an opportunity to challenge dynastic control. Initially the nuns had welcomed Laurence's nomination, offering daily prayers in gratitude for Montmorency's favour; he had reciprocated with goodwill messages, promising to protect the community's rights. All this resembled his sister Anne's succession in I 554-5. But by February I 599 Prioress Jacqueline du Saussay had taken the lead in defying Montmorency's representatives, his physician Ranchin and Barrin. Ranchin was scathing about 'une troupe froquée' governed by envy and passion. Outraged by the prioress' denial of Montmorency's authority over the community and her refusal to surrender the keys so that Madeleine's property could be inventoried, he recommended her exile to her priory of St Michel. ${ }^{45}$ He warned that 'le chasteau visite souvent l'abbaye', suggesting defiance was encouraged by lieutenant-governor Crèvecoeur, Montmorency's distant cousin but also the brother-in-law of madame de Bouteville whose sister was a candidate for abbess. Crèvecoeur, however, later offered Barrin assistance in removing troublemakers from the abbey. To Montmorency's secretary, Ranchin revealed scepticism about the Catholic faith and misogyny, satirically describing his plight 'a la mercy des frocs qui me veulent chasser avec le baston de la Croix et l'eau beniste'. ${ }^{46}$

${ }^{43}$ M. S. Lamet, 'Reformation, war and society in Caen, I 558-i6 io', unpubl. PhD diss. University of Massachusetts 1978,98 , I 5 I.

44 The events can be followed in the correspondence of the main protagonists: Ranchin to Montmorency and Ranchin to Maridat, [before 2 I Feb. I 599], AMC, L xxxiv, fo. 248; xlvi, fo. 238; Barrin to Montmorency, [Jan], Io, 26 June, ı July I599, xxxiv, fo. 249; xlviii, fos 224, 287; xlix, fo. 48; Jacqueline du Saussay to Montmorency, I 4 June, 9 July I 599, xlviii, fo. 250; xlix, fo. 45; Rachel de La Ménardière to Montmorency, 9 July i 599, xlix, fo. 44 (in the same hand as the letter of same date from the prioress); Robert de La Ménardière to Jacqueline du Saussay, [June I599], li, fo. 25I; Montmorency to the community, [minute, June I599], cviii, fo. 98. For comparable cases see R. Pillorget, 'Réforme monastique et conflits de rupture', RH ccliii (I975), 77-ıo6; Blaisdell, 'Religion, gender', I $49^{-54}$.

45 Montmorency's agents were actually transgressing since the prioress traditionally took a leading role on the death of an abbess, including taking an inventory of her property in the presence of the bailli and other royal officers of Caen: BL, Ms Harley 366 I, fos $4,37 \mathrm{v}$.

${ }^{46}$ Ranchin held two priories and aspired to the see of Montpellier before his I608 marriage, but his family was largely Protestant. 
Conflict erupted from Barrin's attempt to enforce observance, particularly enclosure. The prioress demanded 'liberté de la porte', protesting that relations could not visit and claiming that starvation loomed, since Barrin controlled the purse strings and they could not otherwise secure supplies for their table. How far he was moved by vindictive desire to discipline refractory nuns, by genuine devotion to reform, or by concern to maintain Montmorency honour is impossible to assess, although one may question whether he had shown similar rigour during the years he had served under Madeleine de Montmorency's regime. Montmorency himself argued that scandal threatened the community, with the nuns admitting people indiscriminately at all hours and indulging themselves with far too many servants; but did this laxity develop after his sister's demise or was it a longstanding condition? Barrin was, however, convinced of a concerted attempt to undermine the authority of the new abbess, with some nuns claiming her letters of provision were defective.

By June I 599 the prioress had seized upon Rachel de La Ménardière's case as a means of asserting independence from Montmorency's control. Having received the veil from Anne de Montmorency in I574, Rachel had left the abbey in 592 for a priory in the diocese of Chartres but had now returned. Claiming that Madeleine had actually expelled Rachel for her notorious debauchery, Barrin argued that her return, sanctioned by three or four of the older nuns, would compromise the reforms instituted by Montmorency's sister. The prioress believed that Rachel was a victim of Barrin's personal animus, arguing she was a 'bonne religieuse' and a favourite with Madeleine who had permitted her departure only with a papal dispensation. Rachel herself stated that she followed absolutely the regulations and holy example of Montmorency's sisters, and that she had returned to Caen only because of the ruin of her priory in the civil wars. Rhetoric was reinforced by resort to law, encouraged by Rachel's first cousin Robert de La Ménardière who advised appeal to the official or vicar-general of Bayeux, whoever would be more sympathetic; Barrin referred the case to the parlement of Rouen but, on the advice of Laurence de Budos's mother, finally opted for arbitration.

Flowing through Sister Rachel's case were significant political undercurrents, suggesting that it may been a proxy for wider issues. The dynastic interest in this wealthy abbey, challenged by the prioress and her supporters, was not only financial. Louise de Mailly's nomination to Sainte Trinité in I 533 must be seen in the context of strategic family interests. For at least thirty-two years from I53 I, Montmorencys were (largely absentee) governors of the town and chateau of Caen. Louise's uncle, François, seigneur de La Rochepot, inaugurated the sequence and his brother-in-law Charles d'Humières, whose family owed much to Montmorency patronage, became bishop of Bayeux and thus ordinary of Caen, in I 548. On Francois's death in I 55 I, his elder brother constable 
Anne succeeded, securing the survivance for his second son Henri, then seigneur de Damville, in the following year and resigning to him in I 56 I. When Henri formally surrendered this office is uncertain. The lieutenantgovernor of Caen until i 563 was Louis de Neuchèse, seigneur de Batresse, lieutenant of Damville's gendarme company. When Damville, as governor of Languedoc, required Batresse's services in the south, the sieur de Laguo was recommended as replacement but in what capacity is unclear; in I 578, however, it was Laguo whom the king's favourite François d'O succeeded as governor of Caen. ${ }^{47}$

Sainte Trinité was obviously attractive to the Montmorencys who, though landowners in upper Normandy, held nothing in the Caen region; the constable and his nephew, the cardinal de Châtillon, were housed in the abbey during the royal visit in August ${ }_{5} 563 .{ }^{48}$ Local expectations voiced on Abbess Anne's entry were not disappointed. She urged her father and brother Damville to support Caen's attempts to reduce its tax burden in I 566-7; the town's delegates to Paris were favourably received by their governor and his elder brother marshal Montmorency. ${ }^{49}$ The abbesses of Sainte Trinité also acted for their family. Anne gave her father a gold and sapphire ring taken from the tomb of the abbey's founder Queen Matilda, desecrated during the first religious war. ${ }^{50}$ Madeleine's status was invoked when her brother Henri was advised to have payments from the crown assigned on the recette générale of Caen, long after he had ceased to be the town's governor. ${ }^{51}$ Madeleine nurtured the family clientele, reminding Henri to support président François Anzeray, seigneur de Courvaudon, who administered his upper Norman lands, when he sought the survivance of his office in the Rouen parlement for his son. ${ }^{52}$ Madeleine also encouraged closer links between her brother and the governor of Caen, the Languedocian Gaspard de Pelet de La Vérune. Originally a client of Anne de Joyeuse, governor of Normandy, the cousin but also great rival of Montmorency, La Vérune developed ties to the

47 P. Carel, Histoire de la ville de Caen depuis Philippe-Auguste jusqu'à Charles IX, Paris I 886, 258, 287, and Histoire de la ville de Caen sous Charles IX, Henri III et Henri IV, Paris I887, 73; Du Chesne, Histoire généalogique, 440 and preuves at p. 304; D. Potter, War and government in the French provinces, Cambridge, I993, I 3 I-4; K. Leboucq, 'L'Administration provinciale à l'époque des guerres de religion: Henri III, François d'O et le gouvernement de BasseNormandie I 579-88', $R H$ ccxcviii ( I 998), 345-407.

48 While governor of Caen, François d'O found it similarly useful to have his brother Charles abbot of St Etienne, the Ábbaye aux Hommes: Leboucq, 'L'Administration provinciale', 380 .

49 Carel, Caen sous Charles IX, 84 .

${ }^{50}$ Ibid. I9. The May ${ }_{5} 62$ iconoclasts were not deterred by the weeping nuns, including their abbess, kneeling before them.

51 Jean Girard to Montmorency, i 7 Oct. I 595, AMC, L xxiv, fos I68-9; François Bon to Montmorency, Dec. I 597, xxxviii, fo. 272. Noël Hureau and Thomas Morant, receveursgénéraux of Caen, were used by Montmorency in his personal finances.

52 Madeleine de Montmorency to Montmorency, 28 Oct. I 596, AMC, L xxix, fo. 30 I, The Anzerays came from Caen: $D B F$ iii. 86-7. 
ducal branch of the family following his I59 I marriage to Madeleine's distant cousin Jourdaine de Montmorency-Hallot. The abbess mourned La Vérune on his death in I $59^{8}$ as one of her best friends; and she may have advised his uncle-in-law Jacques de Montmorency-Crèvecoeur's succession as governor. ${ }^{53}$

La Rochepot, the first Montmorency governor, was also briefly bailli of Caen in 1537 when his lieutenant was Bertrand Mesnard de La Ménardière, grandfather of Rachel whose presence at Sainte Trinité produced such anguish in I 599. Bertrand, captain of Caen until his death in I550, may have been a Montmorency loyalist: his daughter married into the Anzeray, a family of Montmorency clients. But the Guise affinity, better established than the Montmorencys in Normandy, proved a more powerful pole of attraction for Bertrand's sons and grandsons. Rachel's father saw military service under François duc de Guise in the I 550 os; her uncle Charles was a maittre d'hôtel and then intendant to Guise's brother Claude duc d'Aumale; her uncle Pierre received a benefice from Aumale's mother-in-law, Diane de Poitiers, the favourite of Henri II and rival of Anne constable de Montmorency. Rachel's brother Louis was a monk at Bec under successive Guise abbots. Her first cousin Louis, seigneur de Cuverville, served in Aumale's gendarme company and actively supported the fund-raising of Aumale's nephew Charles duc d'Elbeuf in Rouen in I 588 in support of the Catholic League. Another uncle, Hugues, and his son were killed at Ivry in I 590 fighting for the League. Rachel's first cousin Robert, prior of Sainte Barbe, who supported her cause in I599, became abbot of Sainte Colombe on the resignation of Louis cardinal de Guise in I560. Accounted a 'ligueur de bon foi', Robert attended the League Estates General in I593 and was instrumental in establishing the Jesuits in Caen. ${ }^{54}$ The allegiances of Rachel de La Ménardière's family suggest that the I 599 conflict was not simply focused on monastic reform - whether the key issue was the nomination of an underage abbess, the reintegration of a nun expelled for debauchery, or financial control exercised by a layman. Since the prioress may have been related to a Cotentin family with League links, the case for a political dimension is reinforced. ${ }^{55}$ Although the exiled Aumale was reduced to appealing to Montmorency for intercession with the king, Henri IV signalled his wish to be free of such old rivalries by appointing his bastard son governor of Caen in I599, with Montmorency-Crèvecoeur serving

${ }_{53}$ Madeleine de Montmorency to Montmorency, i 2 Nov. I596, i 8 Apr. I598, AMC, L xxx, fo. 80 ; xl, fo. 252.

54 F. Aubert de La Chenaye des Bois and [?] Badier, Dictionnaire de la noblesse, Paris I 863-76, xiii. 608-I4; S. Carroll, Noble power during the French wars of religion: the Guise affinity and the Catholic cause in Normandy, Cambridge i998, 68, 87, I 2 I .

55 Dr Carroll kindly supplied information about the Saussay family. Charma, 'Note sur une découverte', I 40, suggests that she came from the Angevin family of La Guichardière. 
only as lieutenant. The downturn of Montmorency political fortunes in I6o3 would see Crèvecoeur removed altogether. The outcome of sister Rachel's case is unknown but, in this uncertain political climate, Montmorency presumably decided against offending locally influential nobles, including her brother Hugues, whose seigneuries of Cormelles and Grentheville lay just outside Caen.

Montmorency influenced recruitment to the community even after his pension ceased, so that Caen remained within his patronage network. Three daughters of Montmorency's surintendant Girard became nuns at the abbey. One, having taken her first vows in I 59 I, was professed in I6o3 with four or five girls from the Ile de France who had been received since I 595 on Montmorency's recommendation. Fearing that the Budos regime did not augur well for Montmorency's servants, Girard considered removing this daughter to another abbey closer to Paris but was deterred by the expense; and another daughter was by then a novice. ${ }^{56} \mathrm{~A}$ third Girard daughter was received in I6o8 as was a niece of Montmorency's maître d'hôtel Alphonse Federico. ${ }^{57}$ Laurence de Budos earlier agreed to give the veil to a girl from Languedoc described as the daughter of the sieur de Bacon, but who was almost certainly Montmorency's own daughter from an unacknowledged clandestine marriage contracted before he wed Laurence's sister. ${ }^{58}$ Such patronage did not compromise reform since several beneficiaries of Montmorency favour can be found amongst the supporters of Laurence de Budos. The daughter of monsieur de Blémur, a Montmorency vassal at Ecouen, received in I 596 and professed with Girard's daughter in I6o3, was Geneviève Bouette. As bursar in 1623 she welcomed to the abbey her five-year-old niece Jacqueline Bouette de Blémur, later the hagiographer of Laurence de Budos. ${ }^{59}$ By then Claude Girard was precentress and Michelle Barrin prioress, with Anne Anzeray among the choir nuns, suggesting a persistent Montmorency influence under the Budos regime; but the presence of Angélique de La Ménardière and Cécile du Saussay reveals that

${ }^{56}$ Girard to Montmorency, 25 Aug. I603, AMC, L lxvi, fo. I65. This unnamed daughter was sent to the abbey in 1589 for safety during the troubles of the League when no older than seven. Her sister Marie entered as a novice on 4 January i 598 : contract between Barrin and her parents for her dowry of i oo écus and annuity of 200 livres, i 7 Mar. I598, AN, MC xxiv i 94. A third daughter Anne entered Longchamps in i605, perhaps because of her father's unease about Caen.

57 Procuration from her parents to Noël Hureau, receveur-général of Caen, to agree reception of Claude Girard by the abbess and community of Sainte Trinité, with a dowry of I 50 liores and annuity of 225 livres, 3 Oct. I608, AN, MC LIV 47 I ; Laurence de Budos to Montmorency, Jan. i6o8, AMC, L xc, fo. 57.

${ }^{58}$ Laurence de Budos to Montmorency, Oct. I6o4, AMC, L lxxviii, fo. 28 I.

59 Girard to Castillon, i 7 July I 596, AMC, L xxvii, fo. I I 5 ; $D B F$ vi, I 272-3. Robert Bouette de Blémur was captain of the forest of Montmorency in I 600 when his sister Marie wed François Braque de Luat, another Montmorency client: J. Le Laboureur, Les Tombeaux des personnes illustres, Paris I642, 327. 
challengers of dynastic control also enjoyed continuing status in the community. ${ }^{60}$

Nuns from the extended Montmorency family shared similar experiences to those of other early modern women from aristocratic and elite bourgeois backgrounds. A few were initially reluctant to enter religion but only Françoise de Foix was determined to reject her destiny absolutely. Laurence de Budos's concerns at the age of thirteen may have been shared by other youthful postulants, but must be weighed against Louise de Montmorency's eager embrace of the cloister at a similar age. Yet uncanonical age at reception by no means precluded devotion and enthusiasm for reform as ultimately evinced by Laurence de Budos. This study of the Montmorency female religious reveals, above all, the centrality of dynastic material and political interests: in the decision to make daughters, sisters, sisters-in-law brides of Christ; and in the selection of houses for their entry or eventual governance. Political and direct financial benefits coincided most strikingly in the case of Caen. The ability to secure royal brevets of nomination was a measure of political status, as Montmorency's experiences with Avenay in 1603 and with Caen in both I588 and I598 demonstrated; earlier Maubuisson's destiny was a significant indicator of constable Anne de Montmorency's standing. In the late sixteenth-century French Church, the device of the confidence allowed laity of both sexes to exploit primarily male benefices; notoriously Henri Iv's mistress, Gabrielle d'Estrées, acquired an impressive portfolio of male abbeys in the ${ }^{1590 s}{ }^{61}$ The Abbaye aux Dames's exceptional wealth allowed the unusual situation of a lay male deriving a pension from a female benefice. The role played by Montmorency's surintendant Girard in his dealings with Avenay and Sainte Trinité, and the links of the Barrins, Toussaint and Jacques to Gercy and Caen, parallel the overlap of personnel in the administration of Guise secular and ecclesiastical interests. ${ }^{62}$ Although Montmorency incorporated revenues derived from episcopal sources into the lease of his Languedoc possessions, he seems to have been less bold in his treatment of his financial interest in Sainte Trinité. The administration of his upper Norman lands remained distinct from that of the abbey, despite the links to the community of the Anzerays, members of his Norman administrative council. None the less the close involvement of Montmorency's surintendant Nicolas Girard, himself father of three nuns in the Caen community, in securing Montmorency's pension, and the unambiguous evidence that Jacques Barrin, the abbey's steward and uncle of a future prioress, was primarily a Montmorency agent, lend new emphasis to the term 'family abbey'.

${ }^{60}$ Choir nuns were listed in a service book printed at Caen in I623: Elzière, Histoire, 240 n. $54 \mathrm{I}$.

${ }^{61}$ Bergin, The making of the French episcopate, $35^{\mathrm{I}-7}$; R. Ritter, Charmante Gabrielle, Paris I947, 267-9, 388, 599-6oo. $\quad{ }^{62}$ Bergin, 'The Guises', 37. 